Tobacco industry research

\section{Research from tobacco industry affiliated authors: need for particular vigilance S Chapman}

\section{Is tobacco industry sponsored science ever likely to be trustworthy?}

$\mathrm{T}$ his issue of the Tobacco Control contains an account by Professor

Eiji Yano ${ }^{1}$ complementing an earlier report $^{2}$ about the disturbing circumstances of his association in the early 1990s with tobacco industry lawyers Covington and Burling-specifically, with the company's then employee Christopher Proctor, now head of science and regulation at British American Tobacco (BAT). Dr Proctor and Mr Peter Lee (whom Yano accuses of publishing his research without his consent and distorting its meaning) were given an opportunity to respond to Yano's allegations. Lee has done so, ${ }^{3}$ but Proctor offered no comment.

Proctor forwarded to Yano- - the principal investigator on the study-a succession of drafts of a paper that he hoped Yano would then agree to "author". Lee advised me via email that as statistical consultant to the project he made "considerable" contributions to these drafts which did not bear his name. When Yano refused to agree with the paper based on the data he had collected, Proctor cut him from authorship and elevated long time industry consultant Lee from a status originally planned to be undeclared ${ }^{4}$ to that of sole author. Unlike Lee who had a long history of association with the industry, Yano satisfied its strategic purpose of being a cleanskin researcher who, according to the consultant recruitment plan, had "no previous connection with tobacco companies and no previous record on the primary issue [of secondhand smoke $]^{\prime \prime} .{ }^{5}$ Proctor got rather more than he bargained for, with the earlier published account ${ }^{2}$ of the trail of internal documents alerting Yano to the fate of his work, and stimulating him to set the record straight.

\section{GHOST AUTHORSHIP}

It is hard to imagine a more flagrant example of attempted ghost authorship, a practice described by the World Association of Medical Editors as "dishonest and unacceptable" ${ }^{\prime}{ }^{6}$
The results contained in Lee's published paper ${ }^{7}$ were radically different to those that Yano argues should have been reported. The Lee paper adds to the body of literature featuring many articles by himself which has assisted the industry to argue that studies of secondhand smoke (SHS) are subject to serious problems of misclassification of smoking status, and that therefore policies and laws predicated on the evidence of SHS being harmful are misconceived and should be opposed. Proctor's pivotal role is undeclared in the paper, although Lee acknowledged industry "financial support" but said nothing of what can only have been months of interaction with Proctor over the various drafts on which Lee's name appears.

Lee denies that he "misappropriated" Yano's data, inferring that because he discussed the initial study with Proctor, that this entitled him to use the data to author the paper that was published. Readers will judge for themselves whether Lee's acknowledgement in his paper of Yano's role and his failure to ask Yano for permission to publish Yano's data-knowing that Yano had strongly disagreed with drafts similar to that eventually published-mark the Lee paper as exemplary of the "scientific integrity" Lee says he supports. Remarkably, Lee says that he never saw the phase 2 data from the study he helped design.

\section{SHOULD WE TRUST INDUSTRY SPONSORED SCIENCE?}

This duplicitous episode is yet another in the now well documented history of the tobacco industry's effort to recruit scientists for lawyer managed strategic purposes, ${ }^{8}$ particularly in the case of SHS. ${ }^{9-11}$ This programme of research has produced documented conduct such as failure to disclose competing interests, ${ }^{12}$ "unprecedented scientific fraud", ${ }^{13}$ and data fabrication. ${ }^{14}$ In the notable words of one internal industry document, consultants retained by the industry were said to be "prepared to do the kinds of things they were recruited to $\mathrm{do}^{\prime \prime} .{ }^{15}$

Barnes and Bero ${ }^{16}$ have shown that the only variable explaining the difference in findings of studies on the health risks of SHS is author affiliation to the tobacco industry. Knowing this about the industry's supported research record on SHS, why should we imagine the situation will be any different with regard to its research support for other branches of tobacco related research?

In the Yano episode, the industry had a plain vested interest in discrediting the most famous of all studies on SHS, ${ }^{17}$ as it was acutely aware that the smoking restrictions predicated on SHS being harmful were causing unprecedented reductions in daily consumption by continuing smokers, ${ }^{18} 19$ promoting cessation $^{20}$ and radically redefining the ethical basis for tobacco control. ${ }^{21}$

Should anyone be surprised at such behaviour? Those who work for the tobacco industry are committed by contract of employment to defend and promote its interests. In the words of the Geneva Court of Appeal in the infamous Rylander case ${ }^{22}$ : "Rylander's infringements of scientific integrity take on their full significance only when viewed within the framework of a strategy devised and conducted by the tobacco industry to cast doubt on the toxicity of tobacco smoke, particularly for non-smokers. The case of one person should not make us forget that the most unforgivable fault lies with an institutional and commercial force, the tobacco industry, whose objectives and interests run counter to both public health and medical science." 23

\section{RESEARCH ETHICS}

The tobacco industry does not inhabit the independent research ethos of transparent enquiry that is at the heart of scholarship. While the scientific community strives to be ever more open about its research methods, data sources, and ethical governance, the tobacco industry has shredded documents it anticipated might be incriminating or embarrassing. ${ }^{24}$ It would be unimaginable to see it consent to register all its "health related" trials in the way that is now imminent with pharmaceutical trial registration. ${ }^{25}$

The primary purpose of any research the industry undertakes or commissions is to advance its commercial objectives. Despite what we know from its internal documents ${ }^{26}$ we will never see a public domain paper from a tobacco industry or industry sponsored scientist demonstrating that tobacco advertising is highly influential with children, or that new forms of undeclared nicotine 
analogues ${ }^{27}$ might be even more addictive than nicotine itself. Publication of such inflammatory material would see the industry scientists not long in their jobs, and the grant recipients would not be funded again. Only the profoundly naïve would believe that the tobacco industry would continue to support research which held any promise to harm its bottom line. Tobacco Control has never received such papers from industry sources, and we do not expect to.

So what sort of papers might we expect? The industry has an extensive internal research programme, investing heavily in how to improve the appeal of its products to new and continuing smokers; on monitoring and influencing public perceptions about smoking and tobacco control; on how it can enhance its public credibility while its products kill five million annually; and how its pharmacologists can "make it harder for existing smokers to leave the product". ${ }^{28}$ Understandably, each company has no interest in making such research public or in revealing their hands to their competitors.

However, there are five main areas in which the tobacco industry retains a vital interest in placing research into the public domain to advance its commercial agenda: contesting that SHS is harmful, and that control solutions other than smoke-free policies are acceptable; demonstrating that tobacco advertising has no impact on anyone other than adult smokers ${ }^{29}$; discrediting policy options such as strong health pack warnings that it judges will harm its interests ${ }^{30}$; promoting ineffective youth smoking prevention policies and programs $s^{31}$; and developing less harmful products.

\section{COMMON GROUND?}

The only common ground that the industry has with the public health community is that both are concerned that each year smoking kills millions of smokers early. Plainly, the industry would like to keep more of its best customers smoking longer instead of dying and quitting through health concerns, and since the 1960s has forlornly pursued and promoted the holy grail of the reduced harm cigarette that is addictive but benign. ${ }^{32}$

The case of snus would appear to demonstrate that tobacco products can be developed which are associated with significantly reduced burdens of harm. ${ }^{33}$ While there are no examples of combustible tobacco products demonstrating reduced disease outcomes, the industry has shown that is capable of reducing certain toxins within such products, ${ }^{34}$ although whether this will be of any public health significance is open to serious question.

A recent (2000) memo from a senior BAT scientist put it very plainly:

"Our main problem appears to be the notion that 'the technology exists to make cigarettes which are appreciably less lethal and that many tobacco companies appear to be looking for any excuse not to use it.' The technology does not exist, despite the impression given by the patent record or Star Scientific. It will not exist. All four BAT R\&D Centres have overstated to the companies what they can do in terms of product innovation. This has gone on for a number of years. This is now being picked up by outside pressure groups through patents etc. ... We should tone down future expectations. Firstly, it is not ethical and secondly we shall be asked to explain our failures at some point in the future. ${ }^{\prime \prime 35}$

With such candour from a senior industry figure never being intended for public consumption, we might well question the status and intent of industry research efforts in continuing to pursue the harm reduction agenda 40 years after Ernst Wynder and Dietrich Hoffmann first speculated on its possibilities. $^{36}$ If the exercise today remains little more than an elaborate public relations endgame effort to re-sell a "switch-don't quit" harm reduction message in the face of ever falling smoking prevalence in many nations, how responsible is it to continue to give such research publication oxygen?

\section{SHOULD TOBACCO CONTROL CONSIDER INDUSTRY FUNDED RESEARCH?}

We accept that a policy of not publishing research emanating from the tobacco industry would contribute to the "denormalisation" of the industry. But it would also deprive us of the occasional honest paper, and provide industry lawyers with a means of declaring Tobacco Control "biased" when papers from the journal are submitted in evidence at trials.

Unlike the Journal of Health Psychology and journals published by the American Thoracic Society, ${ }^{38}$ Tobacco Control, like its parent journal the $B M J,{ }^{39}$ has no policy of refusing to consider papers from the industry (or any source) provided they satisfy relevant standards of ethical research conduct. The tobacco industry is not Robinson Crusoe in being a vested interest which influences the research it funds. Barnes' and Bero's findings on tobacco funded research mirror similar studies examining research sponsored by the pharmaceutical $^{40}$ and food ${ }^{41}$ industries. The proposition that all corporately funded research should be excluded from publication would see many research institutions close and many important and entirely ethical collaborations end. A majority of our Editorial Advisory Board supports the continuation of a policy of being open to papers from the industry and its grantees being published, provided they pass peer review.

However, this decision is largely hypothetical. The industry has its own favoured journals where it can publish. ${ }^{42}$ In 14 years we have received only one original article from a tobacco industry scientist (which was rejected after review because of insufficient merit and a "blind spot" where its authors refused to venture). The journal requires authors to declare any competing interests at submission and, with the availability of internal documents, those failing to disclose can often be relatively easily exposed within a few minutes of internet searching.

Because of the history and extent of industry scientific misconduct, we believe it is important that the fullest possible disclosure requirements be established. As Bero et al ${ }^{43}$ have shown, even papers with unusually long disclosure statements about industry support can still fail to provide readers with key information which is important in assessing the extent of an author's industry affiliations. One of our board went so far as to suggest placing a warning on tobacco sponsored articles such as "the data in this article may be fabricated, or the authors may be in possession of unpublished data that refutes it; in any event, the authors have doubtless skewed their analyses and conclusions to serve the purposes of their employers".

We will not go that far, but we will require authors who have any history of affiliation with the tobacco industry or agents acting for it, to declare in full the extent of this affiliation, including the duration and financial scale of support. Any agreements that give a third party power to delay, deny, or vet publication will need to be identified. All individuals who have made any intellectual contribution to a paper should be named, either as authors or in acknowledgements. We are never going to eliminate bias and distortion, but turning arc lights on the possibility of it in this way is likely to greatly assist readers in alerting them to apply the strictest critical appraisal to such papers.

Tobacco Control 2005;14:217-219.

doi: $10.1136 /$ tc. 2005.012427 
Correspondence to: Professor Simon Chapman, School of Public Health, University of Sydney, Building A27, Sydney, NSW 2006, Australia; simonchapman@health.usyd.edu.au

\section{REFERENCES}

1 Yano E. Japanese spousal smoking study revisited: how a tobacco industry funded paper reached erroneous conclusions. Tobacco Control 2005; 14:227-33.

2 Hong MK, Bero LA. How the tobacco industry responded to an influential study of the health effects of secondhand smoke. BMJ 2002;325:1413-6.

3 Lee PN. Japanese spousal study: a response to Professor Yano's claims. Tobacco Control 2005; 14:233-4.

4 Covington \& Burling. Proposal for an applied research study to investigate exposure to environmental tobacco smoke in non-smoking Japanese women. August 1991. http:// legacy.library.ucsf.edu/tid/ipn34e00.

5 Boyse S. (BAT) Note on a special meeting of the UK industry on environmental tobacco smoke, London. Feb $171988 \mathrm{http}: / /$ legacy.library.ucsf.edu/tid/kur45d00

6 World Association of Medical Editors. Ghost writing initiated by commercial companies. http://www.wame.org/wamestmt.htm\#ghost.

7 Lee PN. "Marriage to a smoker" may not be a valid marker of exposure in studies relating environmental tobacco smoke to risk of lung cancer in Japanese non-smoking women. Int Arch Occup Environ Health 1995:67:287-94.

8 Bero L, Barnes DE, Hanauer $P$, et al. Lawyer control of the tobacco industry's external research program. The Brown and Williamson documents. JAMA 1995;274:241-7.

9 Assunta M, Fields N, Knight J, et al. "Care and feeding": the Asian environmental tobacco smoke consultants programme. Tobacco Control 2004;13(suppl II):ii4-12.

10 Barnoya J, Glantz S. Tobacco industry success in preventing regulation of secondhand smoke in Latin America: the "Latin Project". Tobacco Control 2002;11:305-14.

11 Muggli ME, Hurt RD, Blanke DD. Science for hire: a tobacco industry strategy to influence public opinion on secondhand smoke. Nicotine Tob Res 2003;5:303-14.

12 McKee M. Competing interests: the importance of transparency. Eur J Public Health 2003;13:193-4.

13 Diethelm PA, Rielle J-C, McKee M. Authors' reply. Lancet 2005;365:211-2.
14 Chapman S, Penman A. "Can't stop the boy": Philip Morris' use of Healthy Buildings International to prevent workplace smoking bans in Australia. Tobacco Control 2003; 12(suppl III):iii 107-12.

15 Rupp JP, Billings DM. Asia ETS Consultant Status Report. 14 Feb 1990. Philip Morris. Bates No. 2500048976/8998. http://legacy.library. ucsf.edu/tid/zzd58d00.

16 Barnes DE, Bero LA. Scientific quality of original research articles on environmental tobacco smoke. Tobacco Control 1997:6:19-26.

17 Hirayama T. Non-smoking wives of heavy smokers have a higher risk of lung cancer: a study from Japan. BMJ 1981;282:183-5.

18 Chilcote S. Public smoking: the problem (speech). Undated. Bates No. TIMN 0014554-4565. http://tobaccodocuments.org/ti/ TIMN0014554-4565.html.

19 Chapman S, Borland R, Scollo M, et al. The impact of smoke-free workplaces on declining cigarette consumption in Australia and the United States. Am J Public Health 1999:89:1018-23.

20 Fichtenberg CM, Glantz SA. Effect of smoke-free workplaces on smoking behaviour: systematic review. BMJ 2002;325:188.

21 Goodin R. The ethics of smoking. Ethics 1989:99:574-624.

22 Anon. Report of the inquiry into the case involving Prof. Ragner Rylander. (unofficial translation) Geneva, Sept 6 2004. http://www. prevention.ch/rye060904.pdf.

23 Republic and Canton of Geneva. The Judiciary.P/542/01 ACJP/223/03. Decision of the Court of Appeal Criminal Division Hearing of Monday 15 December 2003 http:// www.prevention.ch/ryjue151203.htm

24 Liberman J. The shredding of BAT's defence: McCabe $v$ British American Tobacco Australia. Tobacco Control 2002;11:271-4.

25 A-Jeri KK, Chan A-W, Dickersin K, et al. Principles for international registration of protocol information and results from human trials of health related interventions: Ottawa statement (part 1). BMJ 2005;330:956-8.

26 Cummings KM, Morley CP, Horan JK, et al. Marketing to America's youth: evidence from corporate documents. Tobacco Control 2002; 11 (suppl I):i5-17.

27 Vagg R, Chapman S. Nicotine analogues: a review of tobacco industry research interests. Addiction 2005; 100:701-12.

28 Webb W. (Philip Morris) Status of Marlboro development program. July 12 1984. http:// legacy.library.ucsf.edu/tid/gmr98e00.
29 Boddewyn JJ. There is no convincing evidence for a relationship between cigarette advertising and consumption. Br J Addiction 1989;84:1255-61.

30 Chapman S, Carter SM. "Avoid health warnings on all tobacco products for just as long as we can": a history of Australian tobacco industry efforts to avoid, delay and dilute health warnings on cigarettes. Tobacco Control 2003;12(suppl III):iii13-22.

31 Landman A, Ling PM, Glantz SA. Tobacco industry youth smoking prevention programs: protecting the industry and hurting tobacco control. Am J Public Health 2002;92:917-30.

32 Fields N, Chapman S. Chasing Ernst L Wynder: 40 years of Philip Morris' efforts to influence a leading scientist. J Epidemiol Community Health 2003:57:571-8.

33 Foulds J, Ramstrom L, Burke $M$, et al. Effect of smokeless tobacco (snus) on smoking and public health in Sweden. Tobacco Control 2003:12:349-59.

34 Gray N, Boyle P. The case of the disappearing nitrosamines: a potentially global phenomenon. Tobacco Control 2004;13:13-16.

35 Irwin D. Costing the earth - BBC programme [memo] 2 May 2000. Bates 325153707. http:// tobacco.health.usyd.edu.au/tds/ BAT325153707.

36 Wynder EL, Hoffman D. Reduction of tumorigenicity of cigarette smoke: an experimental approach. JAMA 1965;192:88-94.

37 Marks DF. A higher principle is at stake than simply freedom of speech. BMJ 1996;312:773-4.

38 Rutter T. US journals veto tobacco funded research. BMJ 1996:312:11.

39 King J, Yamey G, Smith R. For and against: why journals should not publish articles funded by the tobacco industry. BMJ 2000;321:1074-6.

40 Lexchin J, Bero LA, Djulbegovic B, et al. Pharmaceutical industry sponsorship and research outcome and quality: systematic review. BMJ 2003;326:1167-70.

41 Levine J, Gussow JD, Hastings D, et al. Authors' financial relationships with the food and beverage industry and their published positions on the fat substitute olestra. Am J Public Health 2003;93:664-9.

42 Garne D, Watson M, Chapman S, et al. Environmental tobacco smoke research published in the journal Indoor and Built Environment and associations with the tobacco industry. Lancet 2005;365:804-9.

43 Bero LA, Glantz S, Hong MK. The limits of competing interest disclosures. Tobacco Control 2005; 14:1 18-26. 